\title{
Apalutamide in combination with autophagy inhibitors improves treatment effects in prostate cancer cells
}

\author{
Eberli, Daniel ; Kranzbühler, Benedikt ; Mortezavi, Ashkan ; Sulser, Tullio ; Salemi, Souzan
}

\begin{abstract}
BACKGROUND ARN-509 (Apalutamide) is a unique androgen receptor (AR) antagonist for the treatment of castration-resistant (CR) prostate cancer (PC). It inhibits AR nuclear translocation, DNA binding and transcription of AR gene targets. As dysregulation of autophagy has been detected in PC, the targeting of autophagy is a potential approach to overcome early therapeutic resistance. Therefore, we investigated the characteristics of autophagic response to ARN-509 treatment and evaluated the potential effect of a combination with autophagy inhibition. METHODS Human prostate cancer cells (LNCaP) were cultivated in a steroid-free medium. Cells were treated with ARN-509 (50 $\mu \mathrm{M})$ alone or in combination with the autophagy inhibitors 3-methyladenine (3MA, $5 \mathrm{mM}$ ) or chloroquine (Chl, $20 \mu \mathrm{M}$ ) or with ATG5 siRNA knock-down. Cell viability and apoptosis were measured by flow cytometry and fluorescence microscopy. Autophagy was monitored by immunohistochemistry, AUTOdot and immunoblotting (WES). RESULTS Treatment with ARN-509 led to cell death of up to 37\% with $50 \mu \mathrm{M}$ and $60 \%$ with $100 \mu \mathrm{M}$ by day 7. The combination of $50 \mu \mathrm{M}$ ARN-509 with autophagy inhibitors produced a further increase in cell death by day 7 . Immunostaining results showed that ARN-509 induced autophagy in LNCaP cells as evidenced by elevated levels of ATG5, Beclin 1 and LC3 punctuation and by an increase in the LC3-II band detected by WES. Autophagic flux was restored by the treatment of cells with Chl, intensifying the LC3-II band. These findings were further supported by an enhanced autophagosome punctuation observed by Autodot staining. CONCLUSIONS These data demonstrate that treatment with ARN-509 leads to increased autophagy levels in LNCaP cells. Furthermore, in combination with autophagy inhibitors, ARN-509 provided a significantly elevated antitumor effect, thus providing a new therapeutic approach potentially translatable to patients.
\end{abstract}

DOI: https://doi.org/10.1016/j.urolonc.2020.04.030

Posted at the Zurich Open Repository and Archive, University of Zurich

ZORA URL: https://doi.org/10.5167/uzh-191325

Journal Article

Published Version

Originally published at:

Eberli, Daniel; Kranzbühler, Benedikt; Mortezavi, Ashkan; Sulser, Tullio; Salemi, Souzan (2020). Apalutamide in combination with autophagy inhibitors improves treatment effects in prostate cancer cells. Urologic oncology, 38(8):683.e19-683.e26.

DOI: https://doi.org/10.1016/j.urolonc.2020.04.030 
Apalutamide in combination with autophagy inhibitors improves treatment effects in prostate cancer cells

Daniel Eberli*, MD, PhD, Benedikt Kranzbühler*, MD, Ashkan Mortezavi, MD, Tullio Sulser, MD, Souzan Salemi **, PhD

${ }^{1}$ University Hospital Zürich, Laboratory for Tissue Engineering and Stem Cell Therapy, Department of Urology, Frauenklinikstrasse 10, CH-8091 Zürich, Switzerland

\section{${ }^{\star *}$ Corresponding author}

Souzan Salemi, PhD, University Hospital

Frauenklinikstr. 10, CH-8091 Zürich, Switzerland

Tel: +41795788654

E-mail: souzan.salemi@usz.ch

* Daniel Eberli and Benedikt Kranzbühler contributed equally to this work.

\section{Highlights}

- Autophagy represents an important resistance mechanism to the novel drug Apalutamide.

- Blocking of autophagy significantly impairs the survival of prostate cancer cell in vitro

- Combination of autophagy inhibitors with Apalutamide has a significant inhibitory effect on LNCaP cells. 


\section{Abstract (350 words)}

Background: ARN-509 (Apalutamide) is a unique androgen receptor (AR) antagonist for the treatment of castration-resistant (CR) prostate cancer (PC). It inhibits AR nuclear translocation, DNA binding and transcription of AR gene targets. As dysregulation of autophagy has been detected in PC, the targeting of autophagy is a potential approach to overcome early therapeutic resistance. Therefore, we investigated the characteristics of autophagic response to ARN-509 treatment and evaluated the potential effect of a combination with autophagy inhibition.

Methods: Human prostate cancer cells (LNCaP) were cultivated in a steroid-free medium. Cells were treated with ARN-509 $(50 \mu \mathrm{M})$ alone or in combination with the autophagy inhibitors 3methyladenine (3MA, $5 \mathrm{mM}$ ) or chloroquine $(\mathrm{Chl}, 20 \mu \mathrm{M})$ or with ATG5 siRNA knock-down. Cell viability and apoptosis were measured by flow cytometry and fluorescence microscopy. Autophagy was monitored by immunohistochemistry, AUTOdot and immunoblotting (WES).

Results: Treatment with ARN-509 led to cell death of up to $37 \%$ with $50 \mu \mathrm{M}$ and $60 \%$ with $100 \mu \mathrm{M}$ by day 7 . The combination of $50 \mu \mathrm{M}$ ARN-509 with autophagy inhibitors produced a further increase in cell death by day 7. Immunostaining results showed that ARN-509 induced autophagy in LNCaP cells as evidenced by elevated levels of ATG5, Beclin 1 and LC3 punctuation and by an increase in the LC3-II band detected by WES. Autophagic flux was restored by the treatment of cells with Chl, intensifying the LC3-II band. These findings were further supported by an enhanced autophagosome punctuation observed by Autodot staining.

Conclusions: This data demonstrates that treatment with ARN-509 leads to increased autophagy levels in LNCaP cells. Furthermore, in combination with autophagy inhibitors, ARN-509 provided a significantly elevated antitumor effect, thus providing a new therapeutic approach potentially translatable to patients.

Key Words: Autophagy, prostate cancer, Apalutamide 


\section{Introduction}

The standard first-line therapy for patients suffering from metastatic prostate cancer (PC) is androgen-deprivation with luteinizing hormone-releasing hormone agonists or antagonists. However, after a period of tumor response, nearly all men progress to castration-resistant prostate cancer (CRPC), which has a high mortality rate ${ }^{1}$. Additional blocking of the androgen receptor (AR) axis by second line agents including Abiraterone acetate and Enzalutamide has proven good antitumor effects in patients with advanced CRPC ${ }^{2,3}$. However, not all patients respond to the therapy, and among those who do, the strength and stability of response can be limited. Apalutamide (ARN-509) is a unique, competitive AR inhibitor, specifically developed for the treatment of CRPC. This novel compound inhibits AR nuclear translocation, DNA binding and transcription of $\mathrm{AR}$ gene targets ${ }^{4}$. To address $\mathrm{PC}$, we previously already investigated the role of autophagy, a cellular self-digestive process that is essential at basal level to ensure homeostasis by the controlled degradation of cellular contents ${ }^{5}$. In addition to an upregulation of autophagy proteins in men with advanced PC, we also provided evidence that enforced downregulation of autophagy accelerates cell death and increases the efficacy of anticancer drugs such as EPI-001 and Abiraterone in prostate cancer cell lines ${ }^{6,7}{ }^{8}$. Given the promising antitumor effect of ARN-509 in the treatment of advanced PC and the role of autophagy as a resistance mechanism against established PC therapy ${ }^{9}$, we aimed to investigate the autophagic response to treatment with ARN-509. Furthermore, we explored the potentially enhanced therapeutic effects of a combination treatment of ARN-509 with autophagy inhibitors in an in vitro model. 


\section{Materials and Methods}

Detailed experimental procedures are provided in supplementary and available online.

\subsection{Cell culture}

The PC cell line LNCaP (CRL-1740, ATCC, Manassas, USA) was cultivated in RPMI (Life Technologies, ThermoFisher SCIENTIFIC, Waltham, MA, USA) supplemented with $10 \%$ FBS and $1 \%$ penicillin/streptomycin and incubated at $37^{\circ} \mathrm{C}$ with $5 \% \mathrm{CO}$. Medium was changed twice a week.

\section{Autophagy inhibition and ARN-509 treatment}

To mimic androgen deprivation, $\mathrm{LNCaP}$ cells were counted and cultured in a steroid-free RPMI medium without phenol red (Life Technologies, Waltham, MA, USA) with 5\% charcoal filtered FBS (F6765, Sigma Aldrich, Buchs, Switzerland) for one day. After one day cells were treated either with ARN-509 (10, 25, 50 and $100 \mu \mathrm{M}$, Janssen Pharmaceutica NV, Belgium), the autophagy inhibitor 3-methyladenine ${ }^{10}$ (3MA, 5 mM, Selleckchem, Luzern, Switzerland), chloroquine (Chl, $20 \mu \mathrm{M}$, Sigma Aldrich) or rapamycin (1-2 $\mu \mathrm{M}$, Selleckchem). For combination treatments, cells were treated with a mixture of ARN-509 and 3MA or ARN-509 and Chl. 


\section{Results}

\subsection{Dose-dependent effect of ARN-509 in LNCaP cells}

In order to investigate the role of autophagy upon anticancer drug treatment, we studied the effect of ARN-509 at sub-lethal concentrations and assessed the level of cell proliferation in the androgen sensitive prostate cancer cell line $\mathrm{LNCaP}$ in different dose and time points. Cells were examined after treatment with different concentrations of ARN-509 in androgen-depleted medium (charcoal filtered) on days 1, 3 and 7. Reduction in cell proliferation was already observed at day 1 , when cells were treated with $10 \mu \mathrm{M}(100 \pm 2.9$, SEM), $25 \mu \mathrm{M}(99 \pm 3.5), 50$ $\mu \mathrm{M}(86 \pm 1.7), 75 \mu \mathrm{M}(84.9 \pm 2.6)$ and $100 \mu \mathrm{M}(86 \pm 1.9)$ of $\mathrm{ARN}-509$ compared to DMSO treated control cells (100\%), with a significance observed with doses of $50 \mu \mathrm{M}$ and above (Figure 1A). The same reduction was observed on day 3 with ARN-509 concentrations of 10 $\mu \mathrm{M}(86 \pm 3.0), 25 \mu \mathrm{M}(85.26 \pm 5.0), 50 \mu \mathrm{M}(73 \pm 9.5), 75 \mu \mathrm{M}(69.7 \pm 2.7)$ and $100 \mu \mathrm{M}(63.7$ \pm 2.1 ) compared to DMSO control. On day 7, the ARN-509 treatment with $10 \mu \mathrm{M}(88.4 \pm 9)$, $25 \mu \mathrm{M}(79.46 \pm 9), 50 \mu \mathrm{M}(62.64 \pm 2.3), 75 \mu \mathrm{M}(48 \pm 3.5)$ and $100 \mu \mathrm{M}(39 \pm 2.9)$ led to further reduction as compared to control. Taken together, a significant cell death in LNCaP cells was induced only in higher concentrations $(50,75$ and $100 \mu \mathrm{M}) \mathrm{ARN}-509$ at all time points as compared to vehicle control (Figure 1A) with a more pronounced effect observed on days 3 and 7. For all subsequent experiments, we proceeded with the efficient dose of $50 \mu \mathrm{M}$ ARN-509.

\subsection{Treatment with anti-cancer drug ARN-509 induces autophagy in LNCaP cells}

To define the role of autophagy in the survival of cancer cells and whether autophagy inhibition can enhance the cell killing effect of ARN-509, LNCaP cells were treated with $50 \mu \mathrm{M}$ ARN509 alone or in combination with the autophagy inhibitors $20 \mu \mathrm{M} \mathrm{Chl}$, or $5 \mathrm{mM} 3 \mathrm{MA}$. Importantly, cells treated with ARN-509 plus 3MA (45.68 \pm 8.0 ,) or ARN-509 plus Chl (37.7 \pm 0.7 ) showed significantly reduced cell proliferation compared to ARN-509 treated cells only 
(75.8 \pm 6.1, SEM) and DMSO control $(97.1 \pm 5.6)$, demonstrating that autophagy plays a part in the cell proliferation mechanism in response to therapy (Figure 1B). As autophagosome formation is one of the main characteristic of autophagy, we explored the link between autophagy related protein expression and autophagosome formation in LNCaP cells upon treatment with ARN-509 and combinations. As assessed by immunofluorescence, both the untreated and DMSO treated cell controls showed low basal expression levels of ATG5, Beclin 1 and weak diffused LC3 staining (Figure 2). ARN-509 treated cells showed an increased cell size, an induced cytoplasmic expression for ATG5 (Figure 2, upper panel) and Beclin 1 (lower panel), and a punctuated pattern for LC3, confirming the accumulation of autophagosomes upon treatment at day 7. The cells treated with a combination of $\mathrm{ARN}-509$ and $5 \mathrm{mM} 3 \mathrm{MA}$, showed a reduced expression of ATG5 and Beclin 1 and no LC3 punctuations with disrupted cell morphology and reduction of cell growth (Figure 2). Moreover, Chl-treated cells in combination with ARN-509 showed accumulation of LC3 protein indicating a Chl-induced accumulation of autophagic vacuoles (Figure 2).

Autophagosome formation was also monitored by AUTOdot fluorescence staining (Figure 3). The LNCaP cells treated with ARN-509 revealed significantly increased autophagosome formation compared to untreated cells or DMSO controls, as identified by enhanced green punctuation in the cells. In addition, ARN-509 treated cells showed the characteristic features of autophagy, such as increased cell size and autophagic vacuoles, cells treated with autophagy inducer, rapamycin served as positive control (Figure 3A and S1). Moreover, cells treated with the combination of ARN-509 and 3MA or Chl showed a significantly increased cell death and a reduced cell number compared to ARN-509 treated cells only. However, Chl-treated cells exhibited a Chl-induced accumulation of autophagic vacuoles in the remaining autophagosomes shown by enhanced green punctuation. Quantification of AUTOdot positive cells indicated that ARN-509 treated cells had a high green punctuation content similar to the one observed by LC3 staining (Figure 3B) which could be blocked in combination conditions. 


\subsection{Combined treatment of ARN-509 with autophagy inhibitors induces apoptosis in LNCaP cells}

We then explored the effect of pharmacological inhibition of autophagy on cell survival in LNCaP cells. Therefore, LNCaP cells were treated with $50 \mu \mathrm{M}$ ARN-509 alone and in combination with the autophagy inhibitors $20 \mu \mathrm{M}$ Chl or $5 \mathrm{mM} \mathrm{3MA}$, and cell viability was measured using ethidium bromide and detected by flow cytometry. An increased rate of cell death was detected in all the experimental conditions compared to DMSO-control on days 1 and 3. However, the most prominent cell death was observed on day 7. An increased rate of cell death was observed in cells treated with ARN-509 (29.97\% $\% 1.9)$, 3MA (46.4 \% \pm 0.7$)$, and Chl (35.4 \% \pm 0.38$)$ compared to DMSO-control (27.02\% $\%$ 3.1). Prominently, a combination treatment of ARN-509+ Chl $(50.3 \% \pm 4.9, \mathrm{P}=0.0006)$ and $\mathrm{ARN}-509+3 \mathrm{MA}(53.2 \% \pm 1.2, \mathrm{P}$ $=0.0001)$ resulted in a significantly reduced cell viability compared to ARN-509 alone. Increased cell death was also linked to a significant increase in apoptosis as measured by Annexin $\mathrm{V}$ assay showing the phosphatidylinositol redistribution in cells upon different treatments. In line with the cell death results, a significant increase in apoptosis was observed in the combination of ARN-509+ Chl $(8.653 \pm 0.16, \mathrm{P}<0.0001)$ compared to single ARN-509 $(2.487 \pm 0.22)$ or $\mathrm{Chl}(2.803 \pm 0.42)$ treatments on day 7 . In contrast, single 3MA $(2.47 \pm 0.88)$ treatment as well as the combination ARN-509 + 3MA (3.12 \pm 0.03$)$ did not induce apoptotic cell death, indicating an induction of cell death via alternative pathways (Figure 4A-B). In parallel, we analyzed the protein expression of ATG5, Beclin 1, LC3 and P62 by immunoblotting. ARN-509 treatment increased the key autophagy markers ATG5 and Beclin 1 (Figure S2) and reduced P62 expression compared to DMSO-treated control (vehicle) (Figure 4C). These results were also confirmed by the conversion of cytosolic LC3-I to membranebound LC3-II detected upon ARN-509 treatment compared to control. Similarly, a combination of either ARN-509 + 3MA or ARN-509 + Chl led to a decrease in LC3-II accumulation (Figure 4C). 


\section{4 siRNA-mediated inhibition of autophagy induces apoptosis in LNCaP cells}

ATG5 has been shown to be essential for the autophagy process. Therefore, to specifically reduce autophagic activity, we blocked the expression of ATG5 by using ATG5 short interfering RNA (siRNA, Figure. 5). Similar to pharmacological treatments, we tested the influence of ATG5 suppression on LNCaP cells and examined the percentage of cell death and apoptosis/necrosis in the cells. Cell death was higher in $30 \mathrm{nM}$ ATG5 siRNA treated cells compared to control $(113 \% \pm 4.2, \mathrm{SD})$ and significantly higher upon combination treatment with ARN-509 $50 \mu \mathrm{M}(139.2 \% \pm 1.6, \mathrm{p}<0.0001)$ (Figure 5A). Moreover, ATG5-suppressed LNCaP cells showed a significantly increased sensitivity towards the effect of ARN-509 (180.5 $\% \pm 9.2, \mathrm{p}<0.0001)$ compared to ARN-509 treatment alone (Figure 5A). Similarly, in comparison to untreated cells and siRNA treated cells $(150.3 \% \pm 16.11$, SEM), an increased susceptibility to apoptosis was detected in cells treated with ARN-509 $(232.2 \% \pm 24.45$, p $<0.0001)$. This effect was significantly enhanced when cells were treated with the combination of ARN-509 plus ATG5 siRNA (355.0\% $\pm 20.6, \mathrm{p}<0.0001)$. No changes were observed in propidium iodide treated cells. The enhanced blockage of ATG5 protein expression via combination of ATG5 siRNA and ARN-509 was confirmed by immunoblotting (Figure 5C). 


\section{Discussion}

In this study, we describe for the first time that Apalutamide (ARN-509) treatment induces prosurvival autophagy in AR expressing prostate cancer cells (LNCaP). Furthermore, we demonstrate that a combination of ARN-509 with autophagy inhibitors significantly increases the antitumor effect in vitro. ARN-509 is a novel competitive inhibitor of the AR and is currently being investigated for the treatment of prostate cancer in different clinical settings. It binds irreversibly to the ligand binding pocket of the AR and shows a 7-10 fold greater affinity to the AR than Bicalutamide. Furthermore, a maximal antitumor effect has been demonstrated at up to 4-fold lower concentrations in the central nervous system compared to Enzalutamide, suggesting a lower seizurogenic potential. In mice xenograft models, ARN-509 showed a dosedependent tumor regression that is greater than the one achieved with Bicalutamide or Enzalutamide ${ }^{4}$. In addition, the safety and efficacy of the compound has been proven in a firstin-human phase I study in metastatic CRPC ${ }^{11}$, while a phase II study reported a significant antitumor activity in patients with non-metastatic CRPC ${ }^{12}$. Recently, the results of the SPARTAN trial led to the approval of Apalutamide $\left(\right.$ Erleada $\left.^{\mathrm{TM}}\right)$ for the treatment of nonmetastatic CRPC ${ }^{13}$. Clinical benefits were also shown in Abiraterone-naïve and Abirateronetreated patients with metastatic CRPC ${ }^{14}$. Ongoing clinical trials are further investigating the role of ARN-509 in different cancer stages ${ }^{15}$.

However, in advanced prostate cancer, cells are capable of adapting and surviving the effects of therapies through different mechanisms ${ }^{16,17}$. In 2013, Joseph et al. described an AR point mutation (AR F877L, formerly AR F876L) as one possible mechanism of acquired resistance to ARN-509 and Enzalutamide ${ }^{18}$. Interestingly, Rathkopf et al. could not confirm AR point mutation $\mathrm{F} 877 \mathrm{~L}$ as contributor to de novo or acquired resistance to $\mathrm{ARN}-509$ in a prospective patient cohort ${ }^{19}$. Another specific mechanism of survival is upregulation of autophagy ${ }^{6,2021}$. Therefore, targeting autophagy is a potential approach to overcome early therapeutic resistance. 
Autophagy is a cellular recycling process that is designed to degrade long-lived proteins and organelles in order to maintain homeostasis in the cells ${ }^{22}$. Several proteins are involved in the autophagy process. Some main elements that are involved in autophagosome formation are ATG12-ATG5 and the microtubule-associated protein 1 light chain 3 (LC3)phosphatidylethanolamine (PE) systems ${ }^{22}$. Here, we report that ATG5, a protein required for autophagosome formation, is upregulated upon ARN-509 treatment and promotes cellular survival in LNCaP cells. In parallel, we observed an elevated Beclin 1 expression with increased levels of LC3. This confirms the novel role of these proteins in mediating protective autophagy and apoptosis in prostate cancer cells. Although WES quantification showed no significance, our results were further confirmed by cell death, apoptosis and autophagy down regulation assays. In addition, we show inhibition of autophagy in cells treated with ARN-509, either pharmacologically or by siRNA knock down of the ATG5 gene. The use of ATG5 siRNA sensitizes LNCaP cells to ARN-509 and induces apoptosis. We have previously shown that the inhibition of autophagy enhances cell-killing effects of Abiraterone acetate in LNCaP cells ${ }^{7}$. In addition, we have shown that combined $\mathrm{N}$-terminal AR binding and autophagy inhibition increases the antitumor effect in Enzalutamide-sensitive and -resistant prostate cancer cells ${ }^{6}$. In line with our findings, growing evidence suggests that autophagy inhibition increases cytotoxicity in combination with several anticancer drugs in preclinical models ${ }^{23,24}$. Several compounds can inhibit autophagy via different pathways at various stages. We have used two autophagy inhibitors to block the autophagy cascade at different stages. 3-methyladenine is a well-established and widely used autophagy inhibitor for in vitro experiments ${ }^{25}$. Based on its inhibitory effect on PI3K activity ${ }^{26}$ it can inhibit at earlier stage of autophagosome formation.

Chloroquine is a well-established, Food and Drug Administration (FDA) -approved autophagy inhibitor, which has been used in the treatment and prevention of malaria ${ }^{27}$. Chloroquine blocks autophagy at later stages in the process by interfering with lysosome acidification and by impairing autophagosome degradation ${ }^{27}$. The general idea of using anticancer therapy in 
combination with autophagy inhibitors for prostate cancer treatment is currently being investigated in clinical trials such as "Akt inhibitor MK2206 and hydroxychloroquine in treating patients with advanced solid tumors or prostate cancer" (Phase I, Identifier: NCT01480154). However, the PANDORA phase II trial could not report a superior efficacy of a combined therapy of docetaxel with autophagy inhibition over docetaxel treatment alone in patients with CRPC ${ }^{28}$. In cells treated with either $3 \mathrm{MA}$ alone or in combination with $50 \mu \mathrm{M}$ ARN-509, cell death has been induced without any effect on the apoptotic machinery. This form of cell death is dependent on autophagy proteins that are involved in the formation of autophagosomes ${ }^{29}$. Conversely, a significant apoptotic cell death was observed when the cells were treated with the combination of ARN-509 and Chl as compared to single ARN-509 or Chl treatments.

In addition, our results and the used concentrations are in line with a recent study by Koukourakis et al. where they compared the effect of $50 \mu \mathrm{M}$ ARN-509 and $100 \mu \mathrm{M}$ ARN-509 to Bicalutamide on androgen receptor expression and kinetics in 22RV1 cells. In this study, ARN-509 showed a stronger antiproliferative effect compared to Bicalutamide, which was more prominent in the androgen receptor expressing cell line 22Rv1. A completely suppressed cell proliferation was observed at a concentration of $100 \mu \mathrm{M}$ ARN-509 ${ }^{30}$. In clinical phase I trial Rathkopf et al. performed a dose escalation to $480 \mathrm{mg}$ daily and did not identify a maximum tolerated dose ${ }^{11}$. In clinical phase II and phase III trials $240 \mathrm{mg}$ daily were used ${ }^{13,31}$. Calculated doses for a $70 \mathrm{~kg}$ patient used in our experiments are $7 \mathrm{x}$ higher than doses used in phase II and phase III trials and $3.4 \mathrm{x}$ higher than the maximum tested dose. However, a direct comparison of concentrations used in vitro to concentrations used in vivo or in patients is not possible. 


\section{Conclusions}

In conclusion, our data indicates that autophagy represents an important resistance mechanism to the novel drug ARN-509. Pharmacological or genetic blocking of autophagy significantly impairs the survival of prostate cancer cell in vitro, implying a therapeutic potential of autophagy inhibitors in combination with AR inhibitors. However, pre-clinical studies investigating the association between ARN-509 therapy and chloroquine are clearly required to prove the efficiency of a dual therapy. 


\section{Conflict of interest}

The authors declare that they have no conflict of interest.

\section{Acknowledgements}

This study was supported by Janssen Pharmaceutical NV. Special thanks to Damina Balmer for the critical assessment of this manuscript. 


\section{Figures}

Figure 1:

Dose-dependent cell proliferation assay of $\mathrm{LNCaP}$ cells in response to $\mathrm{ARN}-50$. A) LNCaP cells were treated with different concentration of ARN-509 5, 10, 25, 50, 75 and $100 \mu \mathrm{M}$ for 1 , 3 and 7 days. B) Cell proliferation in response to combined ARN-509 and autophagy inhibition. LNCaP were cultured in the presence of $50 \mu \mathrm{M}$ ARN-509, $20 \mu \mathrm{M}$ Chl, 5mM 3MA and combinations of $50 \mu \mathrm{M}$ ARN-509 $+20 \mu \mathrm{M}$ Chl and $50 \mu \mathrm{M}$ ARN-509 + 5mM 3MA. Cell proliferation was assessed using WST-1 assay, absorbance was measured at $450 \mathrm{~nm}$ daily. Data represent mean \pm SEM $(n=4)$, in triplicates. All treatment groups were compared to untreated control (corresponding day defined as $100 \%$ ). $* \mathrm{P}<0.05, * * \mathrm{P}<0.01$, *** $\mathrm{P}<0.001$, ****P $<$ 0.0001 showing percentage of growth relative to control.

Figure 2:

Upregulation of ATG5, Beclin 1 and LC3 in ARN-509 treated cells. Confocal images of LNCaP cells treated cells with $50 \mu \mathrm{M}$ ARN-509, $5 \mathrm{mM} 3 \mathrm{MA}, 20 \mu \mathrm{M}$ Chl or a combination of ARN509 and 3MA or ARN-509 and Chl, stained with anti-ATG5, Beclin 1 and LC3 antibodies. Immunofluorescence staining indicates expression of autophagy lineage specific markers ATG5 (upper panel, green color) or Beclin 1 (lower panel, green), and LC3 expression (red). The LC3 punctuation indicates autophagosome formation and high autophagic activity in ARN509 treated cells. Samples were detected using Cy3 (red) conjugated secondary antibody or FITC (green) and DAPI (blue, 4',6-diamidino-2-phenylindole).

Figure 3:

A) LNCaP cells treated with ARN-509 for 7 days and stained with AUTOdot. Significant increase in autophagosomes and punctuation was observed in cells treated with ARN-509. Cells treated with ARN-509 in combination with 3MA or Chl showed significant reduction 
compared to ARN-509 treated cells only. Scale bars: $50 \mu \mathrm{m} \mathrm{B)} \mathrm{Graph} \mathrm{indicates} \mathrm{quantitative}$ measurement of fluorescent intensity using Image $\mathrm{J}$ software. $* \mathrm{p}<0.0001$. $(\mathrm{N}=6$ per condition of microscopic field images).

Figure 4:

Effect of ARN-509 and autophagy inhibition on cells viability, apoptosis, and protein expression in response to combined ARN-509 and autophagy inhibition. LNCaP cells were cultured in the presence of $50 \mu \mathrm{M}$ ARN-509, $20 \mu \mathrm{M}$ Chl, 5mM 3MA and of combinations of $50 \mu \mathrm{M}$ ARN-509+ $20 \mu \mathrm{M} \mathrm{Chl}$ and $50 \mu \mathrm{M}$ ARN-509 + 5mM 3MA. Cell viability was assessed using ethidium bromide and measured by FACS (A). B) Apoptosis was measured by flow cytometry using Annexin V staining. Cells were treated with the above indicated compounds and combinations. Data is shown as mean with standard error of the mean $( \pm$ SEM $)$ of $3-6$ independent experiments. All the treatment groups were compared to vehicle control $(0.1 \%$ DMSO) at day 7. $* \mathrm{P}<0.05, * * \mathrm{P}<0.01, * * * \mathrm{P}<0.001 . \mathrm{C})$ Effects of $50 \mu \mathrm{M}$ ARN-509, $20 \mu \mathrm{M}$ Chl, 5mM 3MA and their combinations on ATG5, Beclin 1, LC3, and p62 protein levels in both cell lines analyzed by immunoblotting.

\section{Figure 5:}

Increasing cell death by dual action of silencing ATG5 and ARN-509 treatment. LNCaP cells were treated with $30 \mathrm{nM}$ ATG5 siRNA, $50 \mu \mathrm{M}$ ARN-509, $50 \mu \mathrm{M}$ EPI + $30 \mathrm{nM}$ ATG5 siRNA and following assays were performed after 7 days of growth upon treatments. A) Cell death was measured using ethidium bromide and analysed by FACS. Values are mean \pm SEM of at least three independent experiments. B) Cell apoptosis assay. Annexin V/PI staining of untreated and treated LNCaP cells. Results are presented as percentage of positive cells compared to control. The data represent the mean \pm SEM $(n=3) . * * p<0.001, * * * p<0.0001$. C) Effects of the ATG5 siRNA on ATG5 and GAPDH levels on LNCaP cells analyzed by immunoblotting. 
Figure S1:

LNCaP cells treated with ARN-509 or Rapamycin for 7 days and stained with AUTOdot. Significant increase in autophagosomes and punctuation was observed in cells treated with both ARN-509 and rapamycin. Cells treated with ARN-509 showed autophagic vacuole formation, which is a typical feature of autophagy. Scale bars: $50 \mu \mathrm{m}$.

Figure S2: WES analysis. Quantification of $50 \mu \mathrm{M}$ ARN-509, $20 \mu \mathrm{M}$ Chl, 5mM 3MA and their combinations on ATG5 and Beclin 1 protein expression. The data represent the mean \pm SEM $(\mathrm{n}=3)$. 


\section{References}

1. Lam JS, Leppert JT, Vemulapalli SN, Shvarts O, Belldegrun AS. Secondary hormonal therapy for advanced prostate cancer. J Urol 2006; 175(1): 27-34.

2. Beer TM, Armstrong AJ, Rathkopf DE, Loriot Y, Sternberg CN, Higano CS et al. Enzalutamide in metastatic prostate cancer before chemotherapy. N Engl J Med 2014; 371(5): 424-433.

3. Ryan CJ, Smith MR, de Bono JS, Molina A, Logothetis CJ, de Souza P et al. Abiraterone in metastatic prostate cancer without previous chemotherapy. N Engl J Med 2013; 368(2): 138148.

4. Clegg NJ, Wongvipat J, Joseph JD, Tran C, Ouk S, Dilhas A et al. ARN-509: a novel antiandrogen for prostate cancer treatment. Cancer Res 2012; 72(6): 1494-1503.

5. Mizushima N, Komatsu M. Autophagy: renovation of cells and tissues. Cell 2011; 147(4): 728741.

6. Kranzbuhler B, Salemi S, Mortezavi A, Sulser T, Eberli D. Combined N-terminal androgen receptor and autophagy inhibition increases the antitumor effect in enzalutamide sensitive and enzalutamide resistant prostate cancer cells. Prostate 2019; 79(2): 206-214.

7. Mortezavi A, Salemi S, Kranzbuhler B, Gross O, Sulser T, Simon HU et al. Inhibition of autophagy significantly increases the antitumor effect of Abiraterone in prostate cancer. World J Urol 2019; 37(2): 351-358.

8. Mortezavi A, Salemi S, Rupp NJ, Ruschoff JH, Hermanns T, Poyet C et al. Negative LC3b immunoreactivity in cancer cells is an independent prognostic predictor of prostate cancer specific death. Oncotarget 2017; 8(19): 31765-31774.

9. Nguyen HG, Yang JC, Kung HJ, Shi XB, Tilki D, Lara PN, Jr. et al. Targeting autophagy overcomes Enzalutamide resistance in castration-resistant prostate cancer cells and improves therapeutic response in a xenograft model. Oncogene 2014; 33(36): 4521-4530.

10. Altznauer F, Conus S, Cavalli A, Folkers G, Simon HU. Calpain-1 regulates Bax and subsequent Smac-dependent caspase-3 activation in neutrophil apoptosis. J Biol Chem 2004; 279(7): 5947-5957.

11. Rathkopf DE, Morris MJ, Fox JJ, Danila DC, Slovin SF, Hager JH et al. Phase I study of ARN509 , a novel antiandrogen, in the treatment of castration-resistant prostate cancer. J Clin Oncol 2013; 31(28): 3525-3530.

12. Smith MR, Antonarakis ES, Ryan CJ, Berry WR, Shore ND, Liu G et al. Phase 2 Study of the Safety and Antitumor Activity of Apalutamide (ARN-509), a Potent Androgen Receptor Antagonist, in the High-risk Nonmetastatic Castration-resistant Prostate Cancer Cohort. Eur Urol 2016; 70(6): 963-970.

13. Smith MR, Saad F, Chowdhury S, Oudard S, Hadaschik BA, Graff JN et al. Apalutamide Treatment and Metastasis-free Survival in Prostate Cancer. N Engl J Med 2018; 378(15): 1408-1418. 
14. Rathkopf DE, Antonarakis ES, Shore ND, Tutrone RF, Alumkal JJ, Ryan CJ et al. Safety and Antitumor Activity of Apalutamide (ARN-509) in Metastatic Castration-Resistant Prostate Cancer with and without Prior Abiraterone Acetate and Prednisone. Clin Cancer Res 2017; 23(14): 3544-3551.

15. Werutsky G, Maluf FC, Cronemberger EH, Carrera Souza V, Dos Santos Martins SP, Peixoto $\mathrm{F}$ et al. The LACOG-0415 phase II trial: abiraterone acetate and ADT versus apalutamide versus abiraterone acetate and apalutamide in patients with advanced prostate cancer with non-castration testosterone levels. BMC Cancer 2019; 19(1): 487.

16. Boudadi K, Antonarakis ES. Resistance to Novel Antiandrogen Therapies in Metastatic Castration-Resistant Prostate Cancer. Clin Med Insights Oncol 2016; 10(Suppl 1): 1-9.

17. Howard N, Clementino M, Kim D, Wang L, Verma A, Shi X et al. New developments in mechanisms of prostate cancer progression. Semin Cancer Biol 2019; 57: 111-116.

18. Joseph JD, Lu N, Qian J, Sensintaffar J, Shao G, Brigham D et al. A clinically relevant androgen receptor mutation confers resistance to second-generation antiandrogens enzalutamide and ARN-509. Cancer Discov 2013; 3(9): 1020-1029.

19. Rathkopf DE, Smith MR, Ryan CJ, Berry WR, Shore ND, Liu G et al. Androgen receptor mutations in patients with castration-resistant prostate cancer treated with apalutamide. Ann Oncol 2017; 28(9): 2264-2271.

20. Zou Z, Yuan Z, Zhang Q, Long Z, Chen J, Tang Z et al. Aurora kinase A inhibition-induced autophagy triggers drug resistance in breast cancer cells. Autophagy 2012; 8(12): 1798-1810.

21. Wu Z, Chang PC, Yang JC, Chu CY, Wang LY, Chen NT et al. Autophagy Blockade Sensitizes Prostate Cancer Cells towards Src Family Kinase Inhibitors. Genes Cancer 2010; 1(1): 40-49.

22. Yang Z, Klionsky DJ. Eaten alive: a history of macroautophagy. Nature cell biology 2010; 12(9): 814-822.

23. Kaini RR, Hu CA. Synergistic killing effect of chloroquine and androgen deprivation in LNCaP cells. Biochem Biophys Res Commun 2012; 425(2): 150-156.

24. Boutin B, Tajeddine N, Vandersmissen P, Zanou N, Van Schoor M, Mondin L et al. Androgen deprivation and androgen receptor competition by bicalutamide induce autophagy of hormoneresistant prostate cancer cells and confer resistance to apoptosis. Prostate 2013; 73(10): 1090-1102.

25. Petiot A, Ogier-Denis E, Blommaart EF, Meijer AJ, Codogno P. Distinct classes of phosphatidylinositol 3 '-kinases are involved in signaling pathways that control macroautophagy in HT-29 cells. J Biol Chem 2000; 275(2): 992-998.

26. Wu YT, Tan HL, Shui G, Bauvy C, Huang Q, Wenk MR et al. Dual role of 3-methyladenine in modulation of autophagy via different temporal patterns of inhibition on class I and III phosphoinositide 3-kinase. J Biol Chem 2010; 285(14): 10850-10861.

27. Rubinsztein DC, Gestwicki JE, Murphy LO, Klionsky DJ. Potential therapeutic applications of autophagy. Nat Rev Drug Discov 2007; 6(4): 304-312. 
28. Hansen AR, Tannock IF, Templeton A, Chen E, Evans A, Knox J et al. Pantoprazole Affecting Docetaxel Resistance Pathways via Autophagy (PANDORA): Phase II Trial of High Dose Pantoprazole (Autophagy Inhibitor) with Docetaxel in Metastatic Castration-Resistant Prostate Cancer (mCRPC). Oncologist 2019; 24(9): 1188-1194.

29. Shimizu S, Kanaseki T, Mizushima N, Mizuta T, Arakawa-Kobayashi S, Thompson CB et al. Role of Bcl-2 family proteins in a non-apoptotic programmed cell death dependent on autophagy genes. Nature cell biology 2004; 6(12): 1221-1228.

30. Koukourakis MI, Kakouratos C, Kalamida D, Mitrakas A, Pouliliou S, Xanthopoulou E et al. Comparison of the effect of the antiandrogen apalutamide (ARN-509) versus bicalutamide on the androgen receptor pathway in prostate cancer cell lines. Anticancer Drugs 2018; 29(4): 323-333.

31. Smith MR, Antonarakis ES, Ryan CJ, Berry WR, Shore ND, Liu G et al. Phase 2 Study of the Safety and Antitumor Activity of Apalutamide (ARN-509), a Potent Androgen Receptor Antagonist, in the High-risk Nonmetastatic Castration-resistant Prostate Cancer Cohort. Eur Urol 2016. 
A.

Day 1

Day 3

Day 7
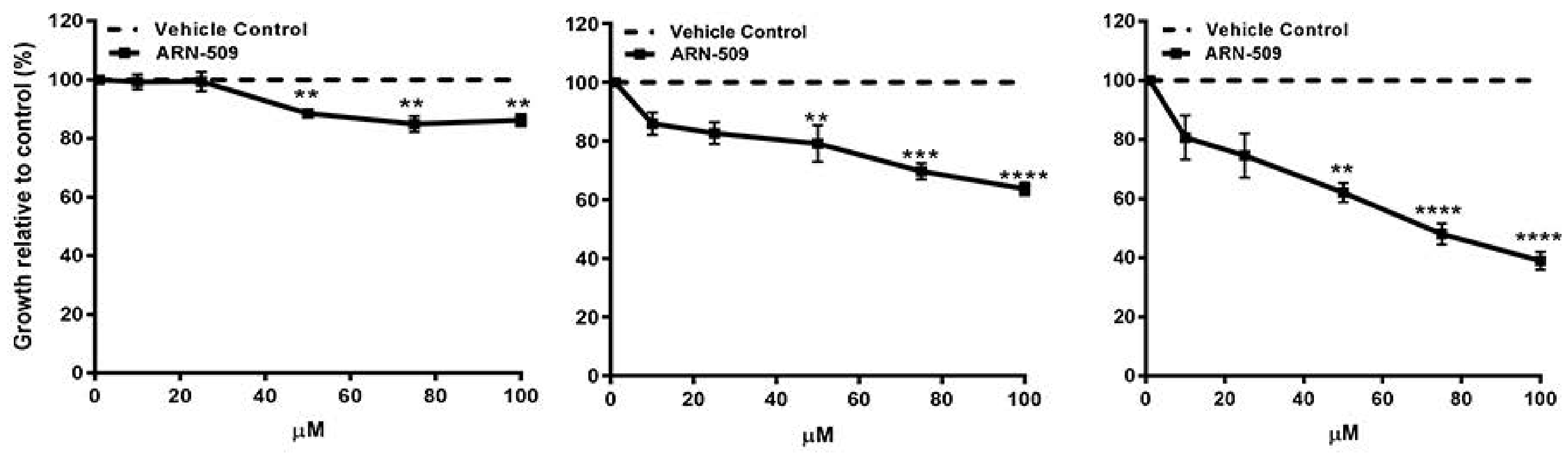

B.

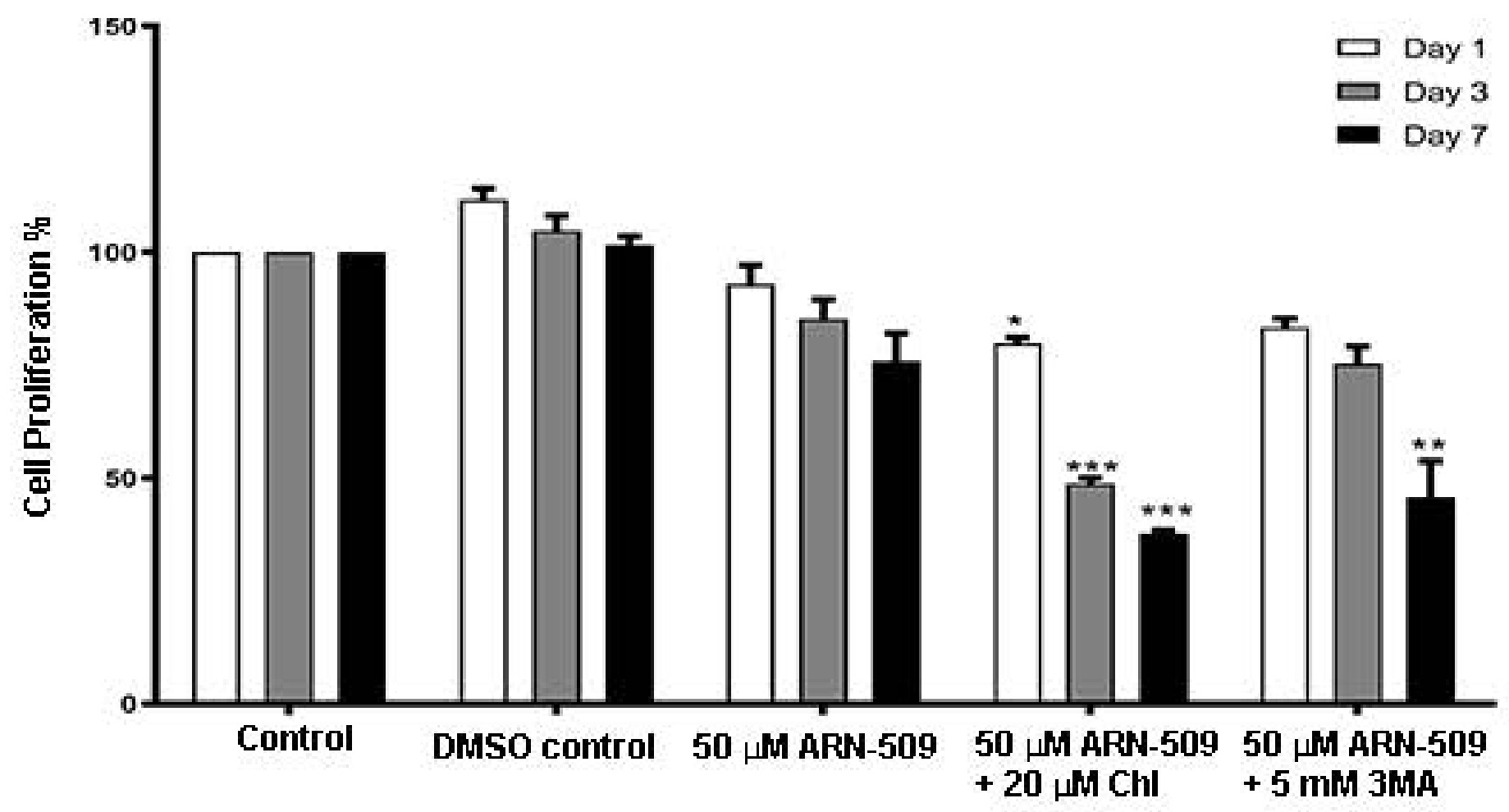

Figure 1 
DMSO control

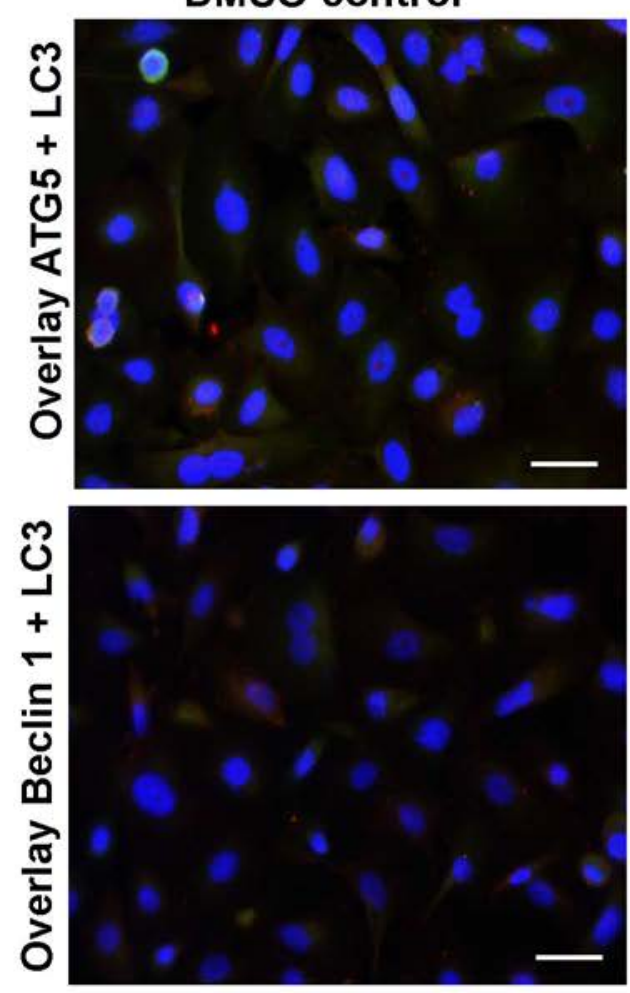

ARN-509 $50 \mu \mathrm{M}$

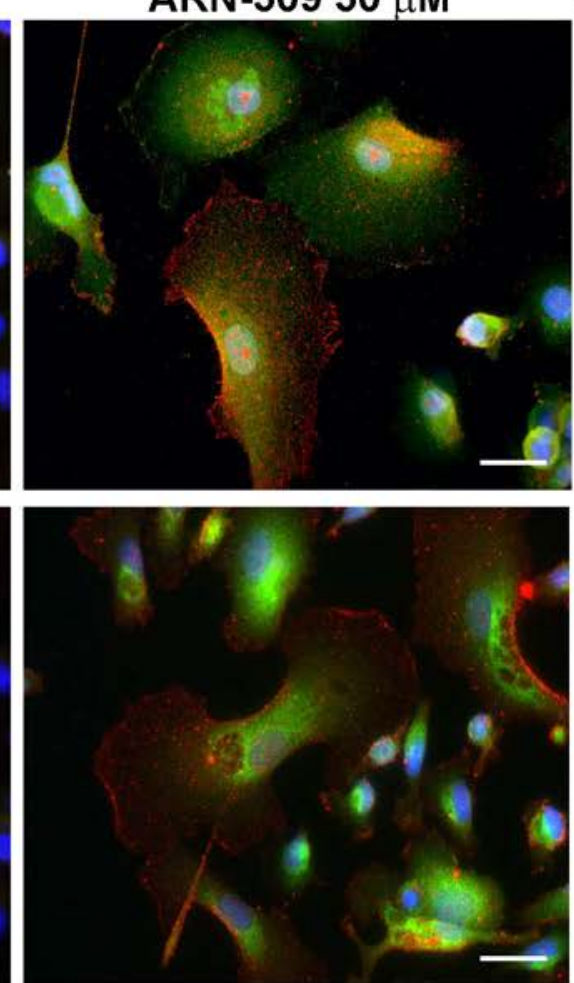

ARN-509 $50 \mu \mathrm{M}+$ Chl $20 \mu \mathrm{M}$ ARN-509 $\mu \mathrm{M}+3 \mathrm{MA} 5 \mathrm{mM}$
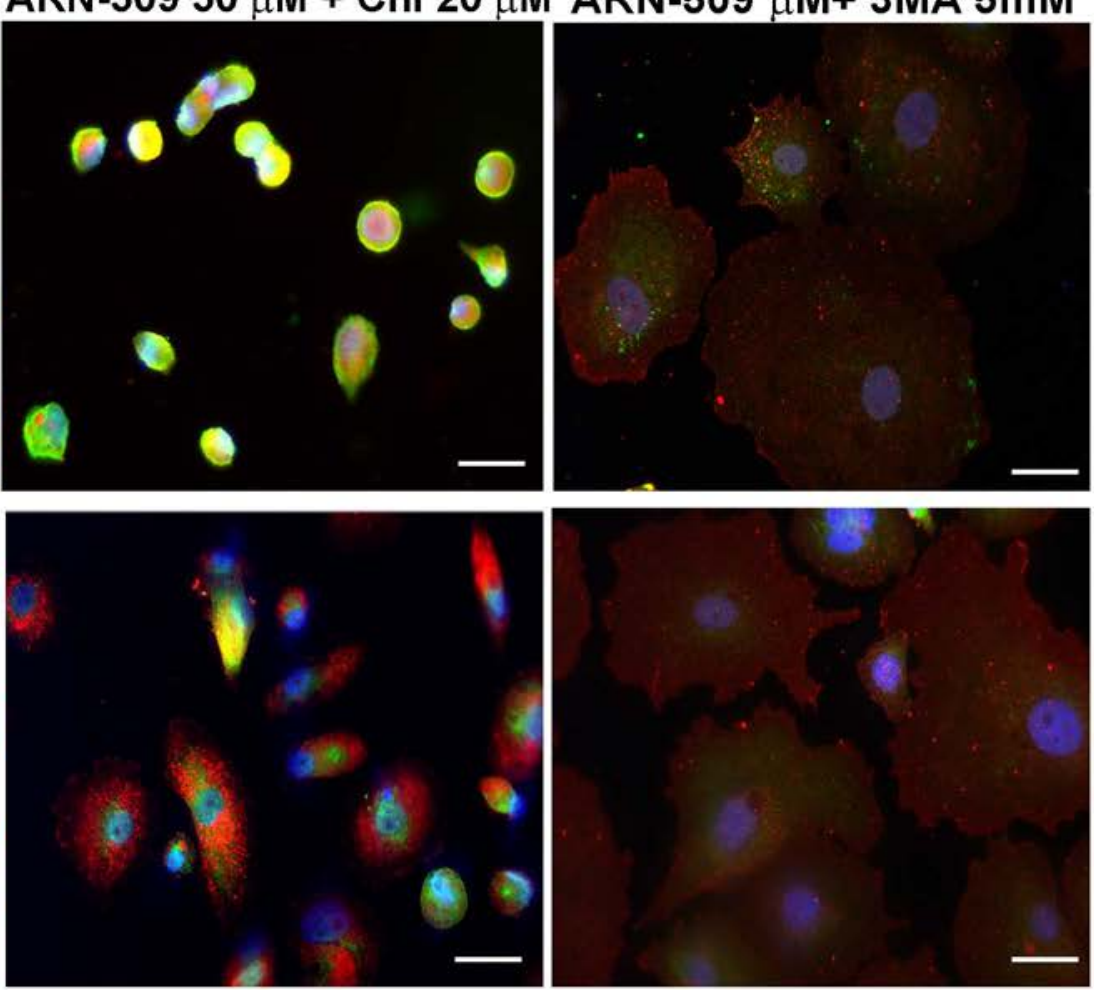
A.
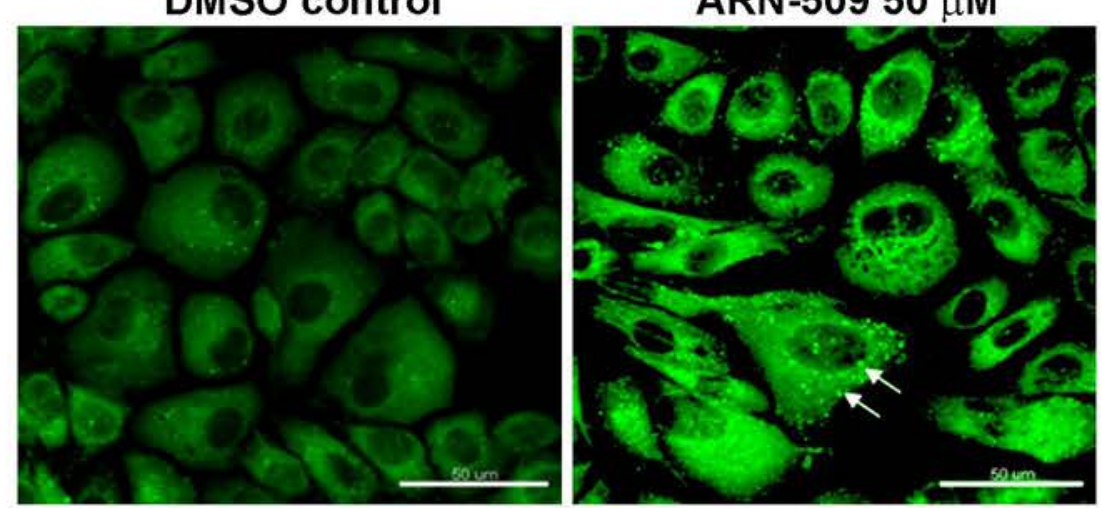

3MA $5 \mathrm{mM}$

ARN-509 $\mu \mathrm{M}+3 \mathrm{MA} 5 \mathrm{mM}$
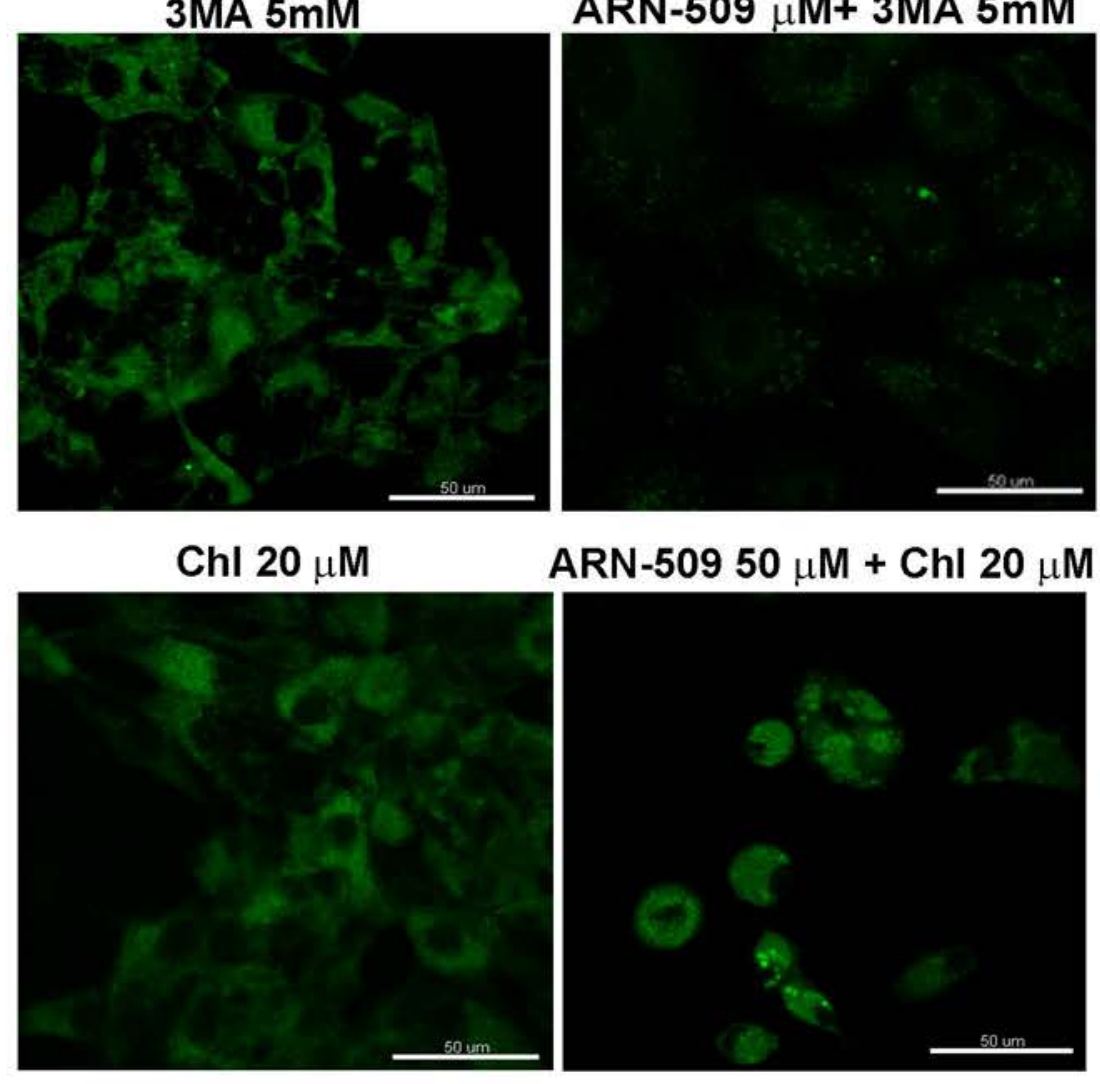

ARN-509 $50 \mu \mathrm{M}+$ Chl $20 \mu \mathrm{M}$

B.

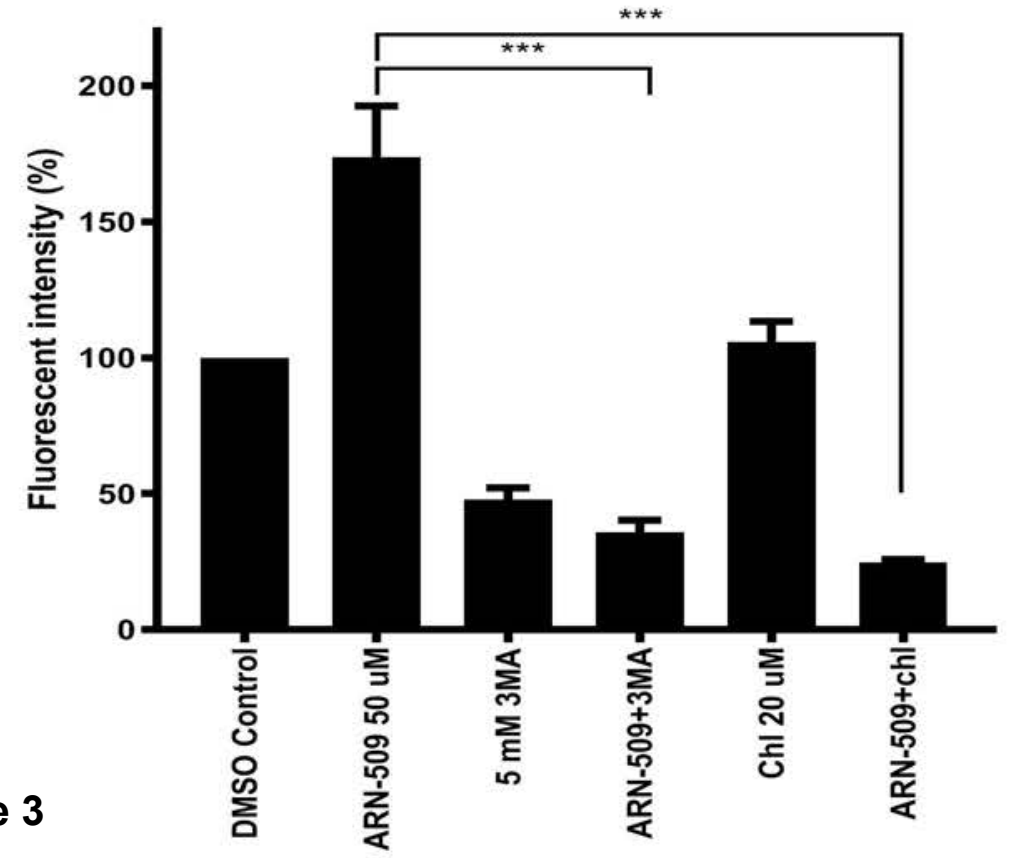

Figure 3

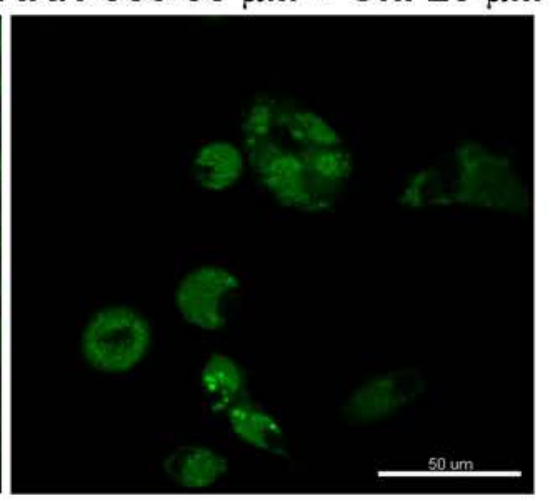


A

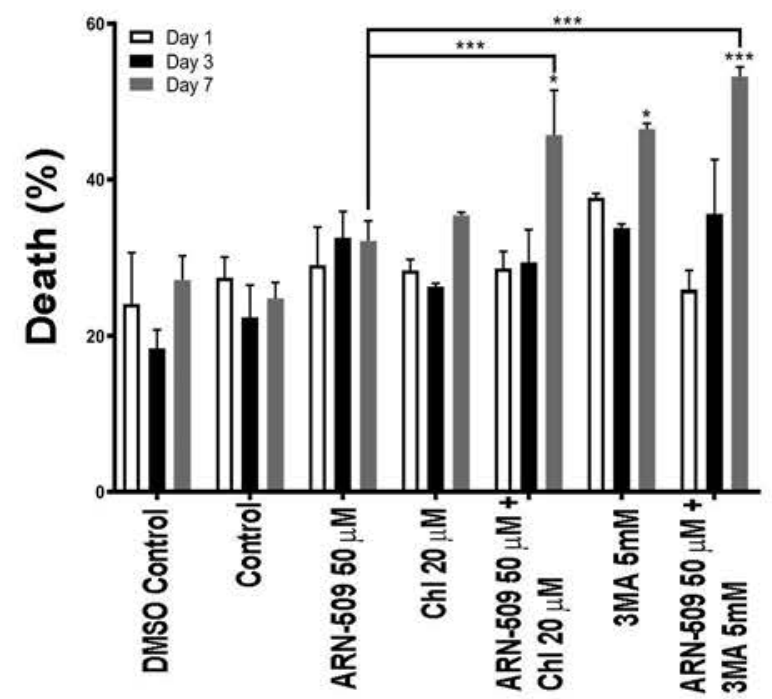

Figure 4

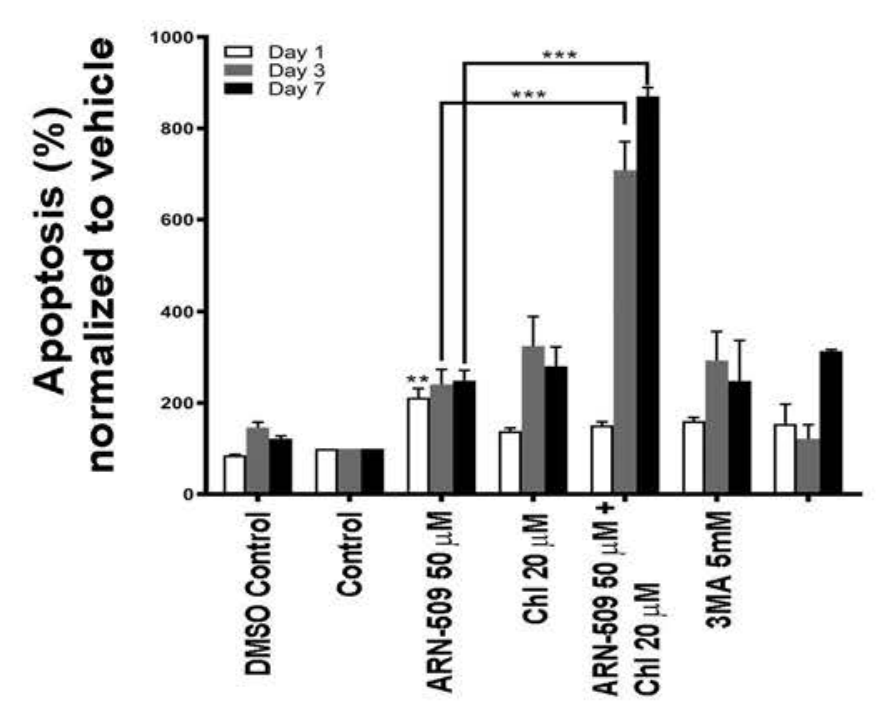

$68=2=-12$ ATG6-ATG12 $68=-\cdots$ Beclin 1 $19 \square=\square$ LC3 I

$63=-\cdots$ P62 $41=$ GAPDH 
A

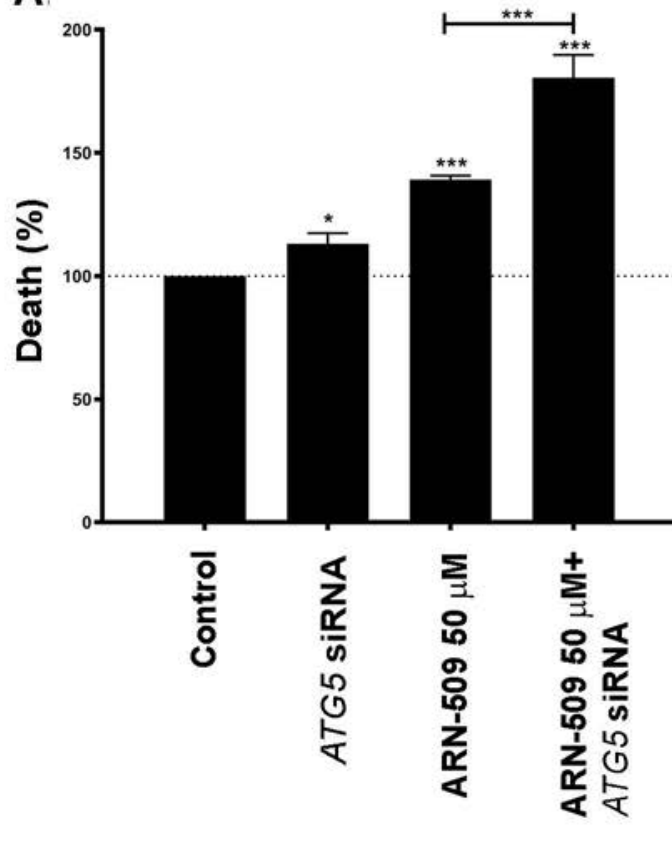

B.

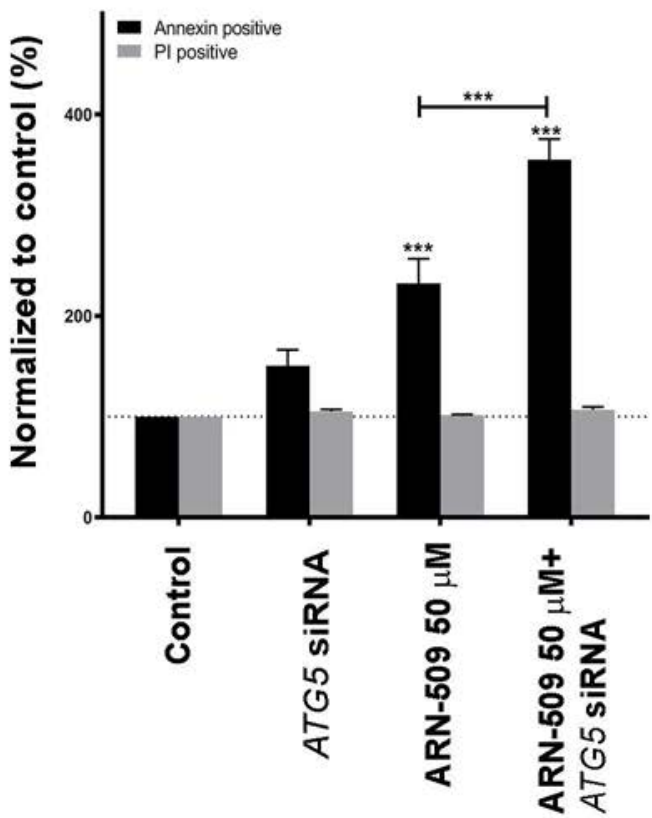

C.

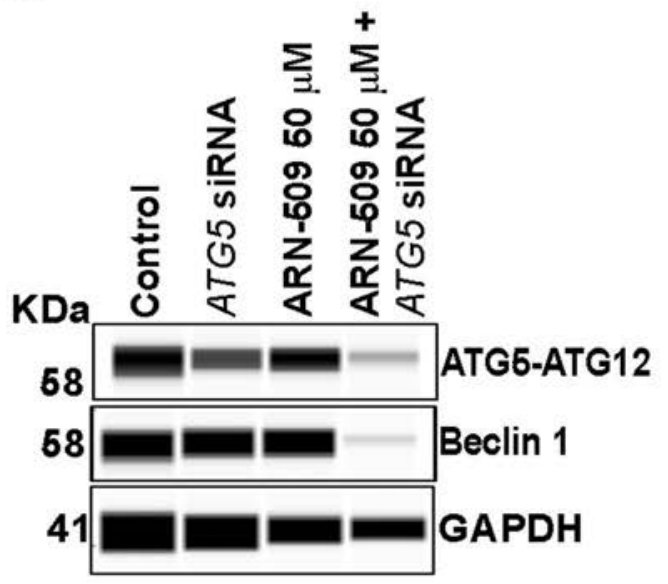

Figure 5

D.

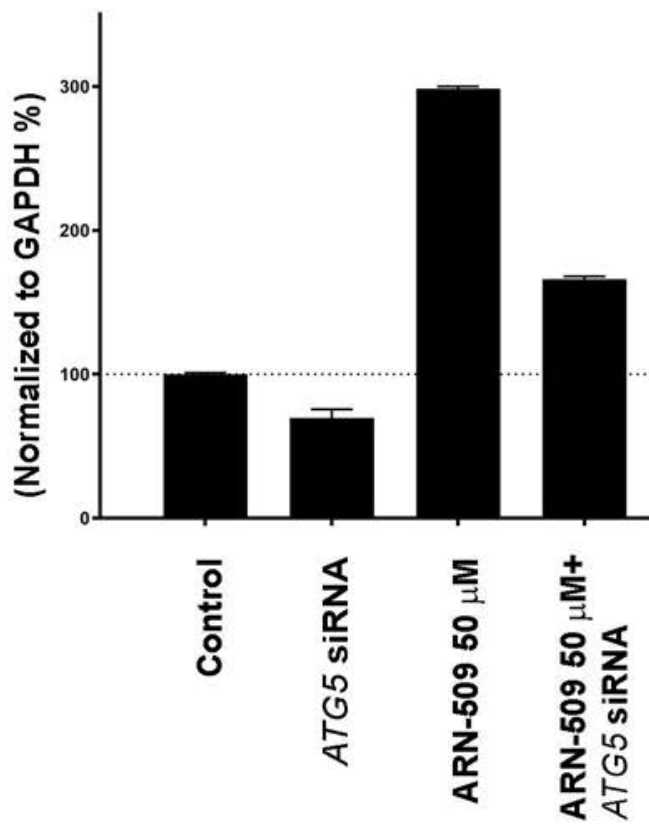




\section{ARN-509 $50 \mu \mathrm{M}$}

Autophagic vacuoles
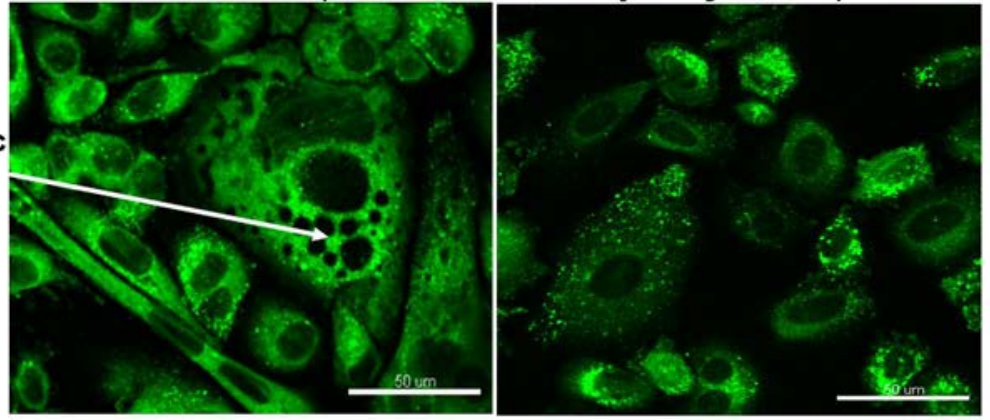

S1 

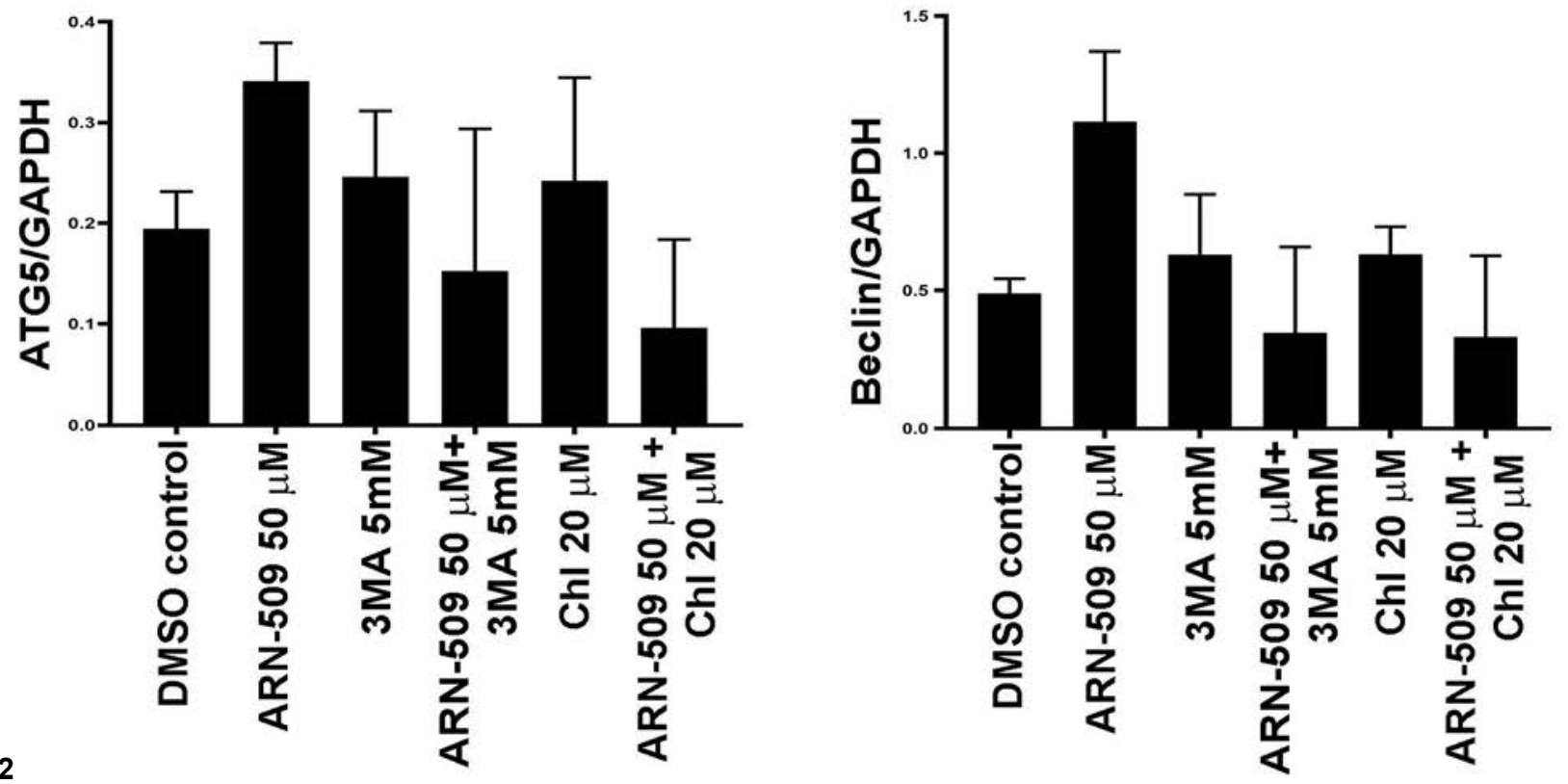


\section{Supplementary Materials and Methods}

\subsection{Cell culture}

The PC cell line LNCaP (CRL-1740, ATCC, Manassas, USA) was cultivated in RPMI (Life Technologies, ThermoFisher SCIENTIFIC, Waltham, MA, USA) supplemented with 10\% FBS and $1 \%$ penicillin/streptomycin and incubated at $37^{\circ} \mathrm{C}$ with $5 \% \mathrm{CO} 2$. Medium was changed twice a week.

\section{Autophagy inhibition and ARN-509 treatment}

To mimic androgen deprivation, LNCaP cells were counted and cultured in a steroid-free RPMI medium without phenol red (Life Technologies, Waltham, MA, USA) with 5\% charcoal filtered FBS (F6765, Sigma Aldrich, Buchs, Switzerland) for one day. After one day cells were treated either with ARN-509 (10, 25, 50 and $100 \mu \mathrm{M}$, Janssen Pharmaceutica NV, Belgium), the autophagy inhibitor 3-methyladenine ${ }^{1}$ (3MA, $5 \mathrm{mM}$, Selleckchem, Luzern, Switzerland), chloroquine (Chl, $20 \mu \mathrm{M}$, Sigma Aldrich) or rapamycin (1-2 $\mu \mathrm{M}$, Selleckchem). For combination treatments, cells were treated with a mixture of ARN-509 and 3MA or ARN-509 and Chl. The media (plus treatments) were changed on day 3. All experiments were performed in triplicates. ATG5 siRNA (SASI_Hs01_00173156, Sigma-Aldrich) transduction was performed 2,3 using N-TER Nanoparticle siRNA Transfection system (Sigma-Aldrich) according to the manufacturer's' protocol.

\subsection{WST-1 cell proliferation assays}

The cell proliferation of treated and untreated cells (control) were measured by WST-1 assay on day 1,3, and 7 according to the manufacturer's protocol (Roche Applied Science, Indianapolis, IN, USA). The cells were incubated with the WST-1 reagent for $3 \mathrm{~h}$ at $37^{\circ} \mathrm{C}, 5 \%$ $\mathrm{CO} 2$ environment and absorbance was measured at $450 \mathrm{~nm}$ on a microplate reader AD340 (Beckman Coulter Inc., Brea,CA, USA). 


\subsection{Cell death assays}

Cell death was measured by ethidium bromide uptake and flow cytometric analysis (FACS, Becton Dickinson FACS Canto flow cytometer) ${ }^{3,4}$. To determine whether cell death was apoptotic, redistribution of phosphatidylserine (PS) was assessed using Annexin V kit (BD Biosciences, Allschwil, Switzerland) and Propidium iodide (Sigma-Aldrich), detected by flow cytometry ${ }^{4}$. Data was evaluated using FlowJo software v. 7.5 (Tree Star Inc., Ashland, Oregon, USA). All data was expressed as a percentage of positive cells.

\subsection{Monitoring autophagosome formation by AUTOdot staining}

Cells were seeded on Lab-Tek chamber slides (Thermo Scientific, Nunc, Switzerland) 1 day prior to the experiments. After treatment of cells according to the indicated stimuli, cells were incubated with AUTOdot (1:1000; Abgent) at $33^{\circ} \mathrm{C}$ for $15 \mathrm{~min}$. Cells were then washed twice with PBS and fixed with $4 \%$ para-formaldehyde before mounting. The excitation filter of AUTOdot was 380 to $420 \mathrm{~nm}$, and the barrier filter was $450 \mathrm{~nm}$. Slides were analyzed by laser confocal microscope (CLSM-SP8, Leica microscope).

\subsection{Protein Simple WES Immunoblotting}

Total protein was measured with the BCA Protein Assay Kit (Thermo Scientific, Lausanne, Switzerland). $1 \mathrm{mg} / \mathrm{ml}$ of protein was used for the WES sample preparation using 12-230 KDa cartridge kit and the proteins were separated in WES with a capillary cartridge according to the manufacturer's protocols (Protein Simple WES, Germany). The primary antibodies for autophagy specific proteins were mouse anti-ATG5 (1:100, nanoTools, Teningen, Germany), rabbit anti-Beclin 1 (1:50, Novus Biologicals Europe, Abingdon, United Kingdom), and mouse anti-LC3 (1:50, Novus Biologicals Europe); mouse anti-GAPDH (1:100, Novus Biologicals Europe) served as internal control.

\subsection{Immunofluorescent staining}


Cells were cultured on Lab-Tek chamber slides in growth medium for 1 day. The next day cells were treated as mentioned in 2.2. The indirect immunostainings for cells were performed at $4{ }^{\circ} \mathrm{C}$ overnight using the primary antibodies Anti- ATG5 (Sigma, 1:100) and LC3 (nanoTools, 1:100). The slides were incubated with secondary antibodies: goat anti-rabbit FITC (Vector Laboratories) or Cy3-conjugated goat anti-mouse antibody (Sigma, 1:1000) at room temperature for $1 \mathrm{~h}$. After counter-staining with DAPI (4',6-diamidino-2-phenylindole, Sigma, 1:200) the slides were analysed with a Leica fluorescence microscope (CTR 6000).

\subsection{Statistical analysis}

All data were analysed by Student's t-test or one-way ANOVA with Bonferroni post analysis ( $p<0.05$ was considered significant). All data presented are expressed as means with corresponding standard error of the mean $( \pm$ SEM) or standard deviation $(\mathrm{SD})$. 


\section{References}

1. Altznauer F, Conus S, Cavalli A, Folkers G, Simon HU. Calpain-1 regulates Bax and subsequent Smac-dependent caspase-3 activation in neutrophil apoptosis. $J$ Biol Chem 2004; 279(7): 5947-5957.

2. Salemi S, Yousefi S, Constantinescu MA, Fey MF, Simon HU. Autophagy is required for selfrenewal and differentiation of adult human stem cells. Cell Res 2012; 22(2): 432-435.

3. Mortezavi A, Salemi S, Kranzbuhler B, Gross O, Sulser T, Simon HU et al. Inhibition of autophagy significantly increases the antitumor effect of Abiraterone in prostate cancer. World J Urol 2018.

4. Altznauer F, Martinelli S, Yousefi S, Thurig C, Schmid I, Conway EM et al. Inflammationassociated cell cycle-independent block of apoptosis by survivin in terminally differentiated neutrophils. J Exp Med 2004; 199(10): 1343-1354. 